\title{
Digital Youth and Their Acquisition of Values When Using the Internet
}

\author{
Mari Carmen Caldeiro-Pedreira ${ }^{1, * \mathbb{C}}$, Paula Renés-Arellano ${ }^{2}$, Cleofé Genoveva Alvites-Huamaní ${ }^{3}$ \\ and Belén González-Larrea ${ }^{4}$
}

1 Department of Pedagogy and Didactics, University of Santiago de Compostela, 27002 Lugo, Spain

2 Department of Education, University of Cantabria, 39005 Santander, Spain; Paula.renes@unican.es

3 Graduate School, University of César Vallejo, Trujillo 13001, Peru; acleofe@ucv.edu.pe

4 Department of Evolutionary and Educational Psychology, University of Salamanca, 37008 Salamanca, Spain; belengonzalezlarrea@usal.es

* Correspondence: mcarmen.caldeiro@usc.es; Tel.: +34-982-821-061

Citation: Caldeiro-Pedreira, M.C.;

Renés-Arellano, P.; Alvites-Huamaní, C.G.; González-Larrea, B. Digital Youth and Their Acquisition of Values When Using the Internet. Sustainability 2021, 13, 11963 . https:// doi.org/10.3390/su132111963

Academic Editor: Barbara Motyl

Received: 16 August 2021

Accepted: 22 October 2021

Published: 29 October 2021

Publisher's Note: MDPI stays neutral with regard to jurisdictional claims in published maps and institutional affiliations.

Copyright: (C) 2021 by the authors. Licensee MDPI, Basel, Switzerland. This article is an open access article distributed under the terms and conditions of the Creative Commons Attribution (CC BY) license (https:/ / creativecommons.org/licenses/by/ $4.0 /)$.

\begin{abstract}
The ability to respond to complex demands in a hypermediated society such as the current one, in young people who navigate the digital world, demands a combination of practical skills, knowledge, values, and social components mobilized together to influence the ways of communicating, acquiring values, and training. Taking this context into account, the following research aims to discover if there is a relationship between the use of the Internet and the social values perceived by university students highlighting the variables of gender, age, and academic year. Regarding the methodology, the type of study is non-experimental with a correlational design, with a sample of 305 university students from the faculties of human and social sciences, as well as education in the Spanish and Chilean context. To collect data on the variable presence of social values, the "Social Values Questionnaire" was developed, and to collect data on variable Internet use, the "Internet Use Questionnaire" was constructed, considering reliability criteria. The results revealed that most university students that use the Internet can identify social values and use them when they communicate with classmates, friends, and family, although with certain differences when looking at the variables analyzed. In conclusion, it is important to promote the ethical and responsible use of the Internet and social networks among young university students because it promotes the development of personal skills and social values.
\end{abstract}

Keywords: higher education; Internet; communication; values; student perception

\section{Introduction}

The Internet has become a tool that is used not only to communicate across vast distances, but to also influence the life, behavior, and attitudes of citizens [1-3]. This new way of communicating has generated, according to Dentzel [4], a social debate on the forms of communication brought about by the Internet. These new ways of communicating between people through the Internet have increased the use of social networks or digital applications [5-7]. These aspects affect social relations because it frees people from their geographical space and at the same time construct new communities. Children, adults, and young people acquire new communication patterns and values that influence their behavior [1,2]. This is a focus of interest of this study, in which it becomes necessary to study how young people perceive the acquisition of values in the digital context in which they live, considering that they acquire specific patterns that influence their development.

Following this line, not only the Internet, but the media, in general, has become a symbolic representation. In this sense, it is noted that "the change from social life to virtual life through social networks is one of the greatest dangers of the abusive use of new technologies for young people" [8] (p. 1). In particular, the Internet and social networks that characterize it, have an undeniable impact on the user's behavior and acquisition 
of values [9-11] because they become generators of content and information [12]. Today, this fact is accentuated, as interactivity has become the modus operandi of society in general and specifically of young people. Instagram, Facebook, Twitter, and YouTube are synchronous and asynchronous communication channels, as stated by authors such as Túnez and Sixto [13], which transmit not only information and content but also values and forms of behavior that influence the construction and development of personality. "The digital generation is being the first to experience a series of drastic changes in accessing and processing information" [8] (p. 2), a fact that irremediably triggers new ways of behaving, acting, and even interpreting the reality to which all young people have access $[14,15]$. These ways of understanding and acting on the Internet with oneself and with others, of acquiring values and behaving on the networks, are some of the questions that have given rise to the study presented in this paper. To this end and considering what the true vision of the protagonists of these networks is, the aim focuses on discovering what the perception of young people is [9] on the use of the Internet and social values. To make understand their views, to detect the possible needs, interests, and realities with which they live within the Network [16] (p. 16) "... the truly important thing is not knowing that he/she is able to produce or consume, or to reflect about what kind of relationships he/she can establish with the media or the environment, but at what expense, with what values and with what ethical principles". In other words, values, ethical behaviors in networks and media are fundamental for a better understanding of these new communication processes. In this sense, it is worth highlighting the statement made by Castells [17] when he indicated that "the Internet is an instrument that develops, but does not change behaviors, but rather behaviors are appropriated by the Internet and, therefore, are amplified and enhanced from what they are" (p. 8). In addition to this, it is worth noting the relevance of the proper use of the Internet and social networks as digital leisure spaces [18] where adolescents socialize [19]. These are places of coexistence and participation; locations in which privacy and identities are established as basic pillars to be safeguarded. Nevertheless, it can be stated that "in general, young people use social networks as an extension of their social life and not as a substitute" [20] (p. 124). However, unquestionably "social networks increase the possibility of individual views, opinions and issues being incorporated into the public sphere" [21] (p. 274), a fact that has a determining influence on the construction of users' personalities. Undeniably, "social networks have become the key tool for communication and interaction among young adolescents that has given rise to a new digital coexistence" [22]. However, social networks also generate addiction and must be analyzed in detail [23]. This is the point where the value of use should be emphasized since technology in itself is not pernicious. The negative aspect lies in the different aspects linked to its use and management. In this sense, the role of education is key to analyzing the different individual and social skills or competencies that society demands specifically and in general. Therefore, it is necessary, as indicated in the title of the Unesco report [24], to rethink education and develop new training approaches [25].

The current situation and context require "new forms of education that foster the competencies that societies and economies need today and tomorrow" [24] (p. 3). Beyond the learning of knowledge, it is necessary to consider the axiological dimension of critical competence [26] needed in the digital society [27]. A media ecosystem [28] in which audiovisual content is spread immediately implies a notable diffusion of values and counter-values [29] that citizens and young people must detect. Therefore, in the academic field, specifically in higher education, it has been observed that the Internet and its tools have taken a fundamental role [30], especially this last year with the pandemic, in which the increase of a digital divide has been noticed [31], or the negative effects of the suspension of classes have been experienced. Faced with this new situation in which social networks are present in a hegemonic way, values, skills, and competencies must be rethought and included in the curricula, because according to Cotino [29], alluding to a United Nations report [32], the use of digital technologies involve risk for human values in education and quality; therefore, they need to be known, evaluated, and acted upon so that they 
are respected. In this sense, some authors [33] state that the arrival of the European Higher Education Area (EHEA) has generated rethinking on how to manage the training of university students, the future professionals who will be agents of change in which they must be educated in ethical, social, and civic values. These are skills that the digital society demands from the so-called millennials [34] or the so-called by Children's Space, Generation T; skills that should be present in the training of all university students since they constitute the future professionals [35]. This means that professionals should use ICTs and multiple devices [36] with minimum skills for accurate performance. Teaching this must be accompanied by new methodologies that adapt to current demands, new ways of teaching among which are active methodologies that favor learning and the acquisition of skills in an active way, focused on the student [37-40]. These are innovative ways of teaching that aim to develop in students, from an early age [41], the necessary skills to identify values and counter-values in the environments to which they are exposed.

These are forms of teaching that take into account emotional competencies [42] directly related to values [43]. In the university context, the Tunning Project refers to values as a fundamental part of the competencies of higher education students. A project that can be considered key to the training of network users who indirectly demand media literacy [16] that empowers them [44]. In addition, it can be stated that values are the cornerstone of education and must be taken into account in the integral education of students that allows them to become active users [45] capable of producing and designing content [46]. This ability to produce and design, not just consume, requires an active role to detect the values transmitted by different media; an aspect that undoubtedly constitutes an advantage when using social networks [47]. That is to say, an education that allows them to participate in on- and off-line life [48]. These reasons justify the interest and need for research such as the one presented here, which seeks, in the digital society also known as multiscreen [49], to understand the perception that the participating sample has of the transmission of values through the Internet.

\section{Materials and Methods}

\subsection{Data Collection}

This study was non-experimental with a correlational design because it aimed to analyze relationships between variables [50]; how they occurred, naturally, without any type of intervention was observed, in order to investigate associations. Likewise, it is considered transactional research $[51,52]$ because it was conducted at a specific moment or a single time.

The objective of the study was to determine the relationship between Internet use and the social values perceived by university students, highlighting the variables of gender, age, and academic year, in terms of whether these values are identified by students when they relate to peers, friends, and family through Internet use.

Throughout the study, when reference is made to Social Values, it considers the following: Friendship, Cooperation, Creativity, Honesty, Equality, Freedom, Respect, Responsibility, and Solidarity. The selection of these values was based on what was specified by some authors in their studies $[33,53,54]$ and with the purpose of understanding which social values had a greater incidence in students. Moreover, a pilot test was conducted, which, as Díaz-Muñoz [55] refers to, is a small study to provide relevant information to improve the methodological and procedural aspects of future research; therefore, a pilot group of 50 university students was selected for this study.

\subsection{Participants}

A non-probabilistic, incidental sampling method was used [56-58], selecting the samples by accessibility to the higher education centers. The study sample consisted of a total of 305 university students from Spanish public universities (3) and one Chilean university, all belonging to the faculties of human and social sciences and education (see Figure 1). In the case of the students, these were in the first and second cycle of their studies, 
with $59 \%$ of them under 20 years of age, 39\% between 20 and 30 years of age, and $2 \%$ over 35 years of age. It should also be noted that the majority were female (85\%).

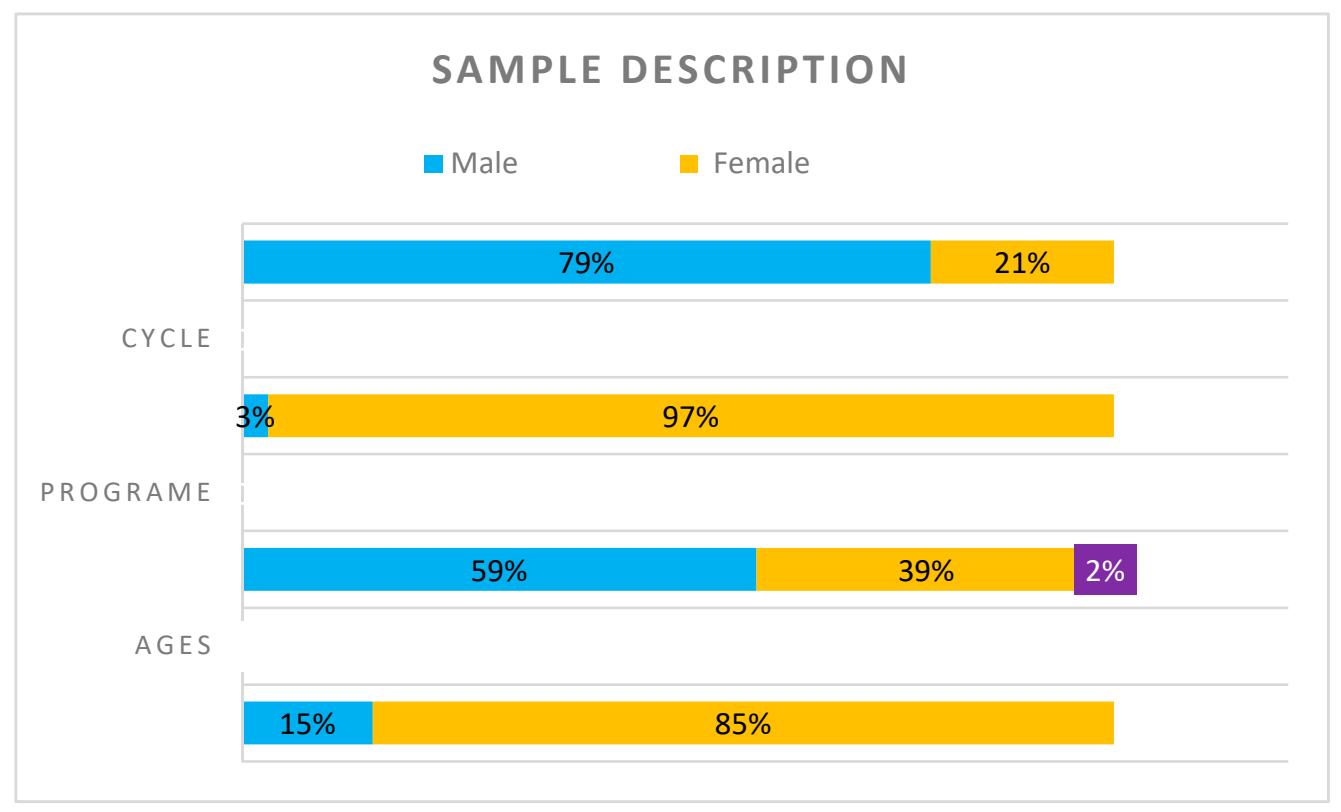

Figure 1. Study sample in percentages.

\subsection{Instruments}

To collect and measure data on the presence of social values variables, the "Social Values Questionnaire" was developed, consisting of five dimensions: (1) Internet transmits values; (2) Internet promotes values; (3) Identification of values with peers in Internet communication; (4) Identification of values with friends in Internet communication; (5) Identification of values with family members in Internet communication, with a total of 37 items and a Likert scale with 5 response options. To develop the questionnaire and determine the validity of the instrument, an expert panel of four university professors who specialized in the subject studied linked to the areas of education and science were used. In addition, convergent validity and discriminant validity were carried out. Positive correlations were considered evidence of convergent validity, while negative correlations and the absence of correlation were considered evidence of discriminant validity [59], and it was analyzed using the Pearson correlation coefficient [60,61]. The questionnaire was completed online by the university students, who answered it voluntarily and confidentially.

Regarding the reliability of the instrument, the analysis was performed with Cronbach's alpha because they were polytomous questions [62]. They obtained a coefficient of 0.865 making it a very reliable instrument, as according to Soler Cárdenas and Soler Pons [63], Cronbach's alpha is a coefficient that takes values between 0 and 1 , and the closer it is to the number 1 , the greater the reliability of the instrument.

For data collection on variable Internet use, the "Internet Use Questionnaire" was constructed (see Table 1), composed of six dimensions: (1) Relevance of Internet use; (2) Years of Internet use; (3) Identification of values with peers in Internet communication; (4) Hours per week of Internet use; (5) Purpose of Internet use to obtain information; (6) Purpose of Internet use for entertainment, with a total of six items, of which five were polytomous and one was dichotomous. Likewise, the analysis to verify the reliability of the instrument was not performed, because the questions were of ordinal scale (qualitative). 
Table 1. Description of the instrument for variable Internet use.

\begin{tabular}{cc}
\hline Dimension & Items \\
\hline Gender & 1 \\
\hline Age & 2 \\
\hline Institution & 3 \\
\hline Specialty & 4 \\
\hline Academic Year & 5 \\
\hline
\end{tabular}

\subsection{Procedure}

To carry out this study, the research had the authorization of the university students, who participated voluntarily and anonymously. Once the results of the questionnaires were completed by the students in Excel, they were organized and categorized by a scale for the test of the presence of social values on the Internet. Likewise, the relationships between variables were analyzed by means of the Spearman's rho non-parametric test for non-normality of the data, which was co-run in SPSS v20 software, with a $p$-value of $<0.05$, which rejects the null hypothesis for each hypothesis.

To verify whether the type of distribution of the data was normal and because the sample was greater than 50, the Kolmogorov-Smirnov goodness-of-fit test was used [62,64,65]. For there to be normality in the data it should be considered that $p=>0.05$, if this is contrasted then parametric tests are used for the statistical contrast [64], but if $p=<0.05$, the distribution is not normal and non-parametric tests are used [62].

As can be seen in Table 2, all variables and dimensions do not present normality for having a $p$-value less than 0.05 ; therefore, Spearman's rho non-parametric test was used to verify the correlation coefficient between the variables $[62,66,67]$.

Table 2. Kolmogorov-Smirnov normality analysis.

\begin{tabular}{cccc}
\hline & \multicolumn{3}{c}{ Kolmogorov-Smirnov } \\
\cline { 2 - 4 } & Statistic & gl & Sig. \\
\hline Relevance of Internet usage & 0.396 & 305 & 0.000 \\
\hline Years of Internet use & 0.326 & 305 & 0.000 \\
\hline Hours per week of Internet use & 0.313 & 305 & 0.000 \\
\hline $\begin{array}{c}\text { Purpose of Internet use to } \\
\text { obtain information }\end{array}$ & 0.371 & 305 & 0.000 \\
\hline Purpose of Internet use to communicate & 0.358 & 305 & 0.000 \\
\hline Purpose of Internet use entertainment & 0.269 & 305 & 0.000 \\
\hline Internet transmits values & 0.514 & 305 & 0.000 \\
\hline Internet promotes values & 0.380 & 305 & 0.000 \\
\hline Values with peers & 0.527 & 305 & 0.000 \\
\hline Values with friends & 0.529 & 305 & 0.000 \\
\hline Values with family members & 0.519 & 305 & 0.000 \\
\hline Values in general & 0.521 & 305 & 0.000 \\
\hline Gender & 0.511 & 305 & 0.000 \\
\hline Age & 0.381 & 305 & 0.000 \\
\hline Institution & 0.249 & 305 & 0.000 \\
\hline Specialty & 0.323 & 305 & 0.000 \\
\hline Academic year & 0.487 & 305 & 0.000 \\
\hline
\end{tabular}




\section{Results}

The results of the research were based on the hypotheses proposed and the corresponding treatment of the data obtained. In the first instance, and referring to Table 1, it was observed that student perception regarding the identification of social values is significantly related to gender, age, institution, and academic year. A medium positive correlation was found for gender $(p=0.049)$ and academic year $(p=0.049)$ [68]. Therefore, the general hypothesis $\left(\mathrm{H}_{1}\right)$ is accepted: There is a relationship between Internet use and social values from the perception of university students with regards to the purpose of using the Internet, according to gender and academic year (Table 3).

Table 3. Relationship between Internet use and the identification of social values in general, according to the purpose of Internet use for communication.

\begin{tabular}{|c|c|c|c|}
\hline \multirow{2}{*}{\multicolumn{2}{|c|}{ Presence of Values on the Internet }} & \multicolumn{2}{|c|}{ Use of the Internet } \\
\hline & & \multicolumn{2}{|c|}{ Purpose of Internet Use for Communication } \\
\hline & Students' perception & Spearman's correlation & Sig. \\
\hline \multirow{3}{*}{$\begin{array}{l}\text { Identification of } \\
\text { values (general) }\end{array}$} & According to Gender & 0.113 & $0.049 *$ \\
\hline & According to Age & 0.103 & 0.074 \\
\hline & $\begin{array}{l}\text { According to } \\
\text { Academic year }\end{array}$ & 0.113 & $0.049 *$ \\
\hline
\end{tabular}

${ }^{*} p<0.05$ significant difference. Source: By the authors (2021).

In Table 4, it is observed that the relevance of internet use is related to the internet transmitting values according to gender $(p=0.037)$ and academic year $(p=0.039)$, showing within the range of average negative correlation; while the years of internet use is related to the internet transmitting values according to gender $(p=0.029)$, specialty $(p=0.028)$, and academic year $(p=0.024)$. Likewise, the purpose of internet use for entertainment is related to the internet transmitting values according to gender $(p=0.029)$, age $(p=0.045)$, and academic year $(p=0.031)$; showing the latter as values within the range of medium positive correlation. Therefore, the general hypothesis (H2) is accepted: There is a relationship between Internet use and the Internet transmitting values, according to the relevance of Internet use, years of Internet use, and the purpose of Internet use for communication.

Table 4. Relationship between Internet use and Internet transmitting values according to relevance of Internet use, years of Internet use, and purpose of Internet use for communication.

\begin{tabular}{|c|c|c|c|c|c|c|c|}
\hline \multirow{2}{*}{\multicolumn{2}{|c|}{$\begin{array}{c}\text { Presence of Values } \\
\text { on the Internet }\end{array}$}} & \multicolumn{6}{|c|}{ Use of the Internet } \\
\hline & & \multicolumn{2}{|c|}{$\begin{array}{l}\text { Relevance of } \\
\text { Internet Use }\end{array}$} & \multicolumn{2}{|c|}{ Years of Internet Use } & \multicolumn{2}{|c|}{$\begin{array}{l}\text { Purpose of Internet Use } \\
\text { for Entertainment }\end{array}$} \\
\hline & $\begin{array}{l}\text { Students' } \\
\text { perception }\end{array}$ & $\begin{array}{l}\text { Spearman's } \\
\text { correlation }\end{array}$ & Sig. & $\begin{array}{l}\text { Spearman's } \\
\text { correlation }\end{array}$ & Sig. & $\begin{array}{l}\text { Spearman's } \\
\text { correlation }\end{array}$ & Sig. \\
\hline \multirow{3}{*}{$\begin{array}{l}\text { Internet } \\
\text { transmits } \\
\text { values }\end{array}$} & $\begin{array}{l}\text { According } \\
\text { to Gender }\end{array}$ & -0.119 & 0.037 * & 0.125 & $0.029 *$ & 0.125 & $0.029 *$ \\
\hline & $\begin{array}{l}\text { According } \\
\text { to Age }\end{array}$ & -0.111 & 0.053 & 0.163 & 0.004 * & 0.115 & $0.045 *$ \\
\hline & $\begin{array}{l}\text { According to } \\
\text { Academic year }\end{array}$ & -0.119 & $0.039 *$ & 0.130 & $0.024 *$ & 0.124 & $0.031 *$ \\
\hline
\end{tabular}

${ }^{*} p<0.05$ significant difference. Source: By the authors (2021).

In Table 5 , it is observed that the use of the Internet and the Internet promoting values for the purpose of using the Internet to communicate, according to gender $(p=0.041)$, age $(p=0.026)$, and academic year $(p=0.045)$ are in a range of average positive correlation. Therefore, the general hypothesis (H3) is accepted: There is a relationship between Internet use and the Internet promoting values, according to the purpose of Internet use for communication. 
Table 5. Relationship between the use of the Internet and the Internet promoting values, according to the purpose of using the Internet to communicate.

\begin{tabular}{llcc}
\hline \multirow{2}{*}{ Presence of Values on the Internet } & \multicolumn{2}{c}{ Use of the Internet } \\
\cline { 2 - 4 } & \multicolumn{2}{c}{$\begin{array}{c}\text { Purpose of Using the } \\
\text { Internet to Communicate }\end{array}$} \\
\hline \multirow{3}{*}{ Internet promotes values } & According to Gender & 0.117 & Sig. \\
\cline { 2 - 4 } & According to Age & 0.128 & $0.041^{*}$ \\
\cline { 2 - 4 } & $\begin{array}{c}\text { According to } \\
\text { Academic year }\end{array}$ & 0.115 & $0.045^{*}$ \\
\hline
\end{tabular}

${ }^{*} p<0.05$ significant difference. Source: By the authors (2021).

Table 6 shows that Internet use and social values in the category of values used in communication with peers on the Internet for the purpose of using the Internet to communicate according to gender $(p=0.022)$, age $(p=0.027)$, and academic year $(p=0.021)$ are in a range of average positive correlation. Therefore, the general hypothesis (H4) is accepted: There is a relationship between Internet use and social values in the category of values used in communicating with peers on the Internet, according to the purpose of using the Internet to communicate.

Table 6. Relationship between Internet use and social values in regarding values used in communicating with peers on the Internet, according to the purpose of using the Internet to communicate.

\begin{tabular}{cccc}
\hline \multirow{2}{*}{ Presence of Values on the Internet } & \multicolumn{2}{c}{ Use of the Internet } \\
\cline { 2 - 4 } & \multicolumn{2}{c}{$\begin{array}{c}\text { Purpose of Using the } \\
\text { Internet to Communicate }\end{array}$} \\
\hline \multirow{2}{*}{$\begin{array}{c}\text { Values used in } \\
\text { communicating with } \\
\text { peers on the Internet }\end{array}$} & According to Gender & 0.131 & $0.022 *$ \\
\cline { 2 - 4 } & According to Age & 0.127 & $0.027^{*}$ \\
\cline { 2 - 4 } & $\begin{array}{c}\text { According to } \\
\text { Academic year }\end{array}$ & 0.132 & $0.021 *$ \\
\hline
\end{tabular}

${ }^{*} p<0.05$ significant difference. Source: By the authors (2021).

Table 7 shows that Internet use and social values regarding values used in communication with friends on the Internet for the purpose of using the Internet to communicate according to gender $(p=0.004)$, age $(p=0.004)$, and academic year $(p=0.004)$ are in a weak positive correlation range.

Table 7. Relationship between Internet use and social values in regarding values used in communicating with friends on the Internet, according to the purpose of using the Internet to communicate.

\begin{tabular}{cccc}
\hline \multirow{2}{*}{\begin{tabular}{c} 
Presence of Values on the Internet \\
\cline { 2 - 3 }
\end{tabular}} & \multicolumn{2}{c}{$\begin{array}{c}\text { Use of the Internet } \\
\text { Internet to Communicate }\end{array}$} \\
\hline \multirow{2}{*}{$\begin{array}{c}\text { Values used in } \\
\text { communicating with } \\
\text { friends on the Internet }\end{array}$} & Students' perception & Spearman's correlation & Sig. \\
\cline { 2 - 4 } & According to Gender & 0.163 & $0.004^{*}$ \\
\cline { 2 - 4 } & According to Age & 0.166 & $0.004^{*}$ \\
\hline Ap According to & $0.004^{*}$ \\
\hline
\end{tabular}

Therefore, although with some weakness, it is considered that the general hypothesis (H5) is accepted: There is a relationship between Internet use and social values regarding values used in communicating with friends on the Internet, according to the purpose of using the Internet to communicate. 
Table 8 shows that Internet use and social values in the category of values used in communication with family members on the Internet for the purpose of using the Internet to communicate according to gender $(p=0.035)$, age $(p=0.048)$, and academic year $(p=0.041)$ are in a range of average positive correlation. Therefore, the general hypothesis (H6) is accepted: There is a relationship between Internet use and social values in the category of values used in communicating with family members on the Internet, according to the purpose of using the Internet to communicate.

Table 8. Relationship between Internet use and social values regarding the values used in communicating with family members on the Internet, according to the purpose of using the Internet to communicate.

\begin{tabular}{cccc}
\hline \multirow{2}{*}{ Presence of Values on the Internet } & \multicolumn{2}{c}{ Use of the Internet } \\
\cline { 2 - 3 } & Students' perception & \multicolumn{2}{c}{$\begin{array}{c}\text { Purpose of Using the } \\
\text { Internet to Communicate }\end{array}$} \\
\hline \multirow{2}{*}{$\begin{array}{c}\text { Values used when } \\
\text { communicating with family } \\
\text { members on the Internet }\end{array}$} & According to Gender & 0.121 & Sig. \\
\cline { 2 - 4 } & According to Age & $0.035^{*}$ \\
\cline { 2 - 4 } & $\begin{array}{c}\text { According to } \\
\text { Academic year }\end{array}$ & 0.114 & $0.048^{*}$ \\
\hline$p<0.05$ significant difference. Source: By the authors (2021). & & $0.041^{*}$ \\
\hline
\end{tabular}

\section{Discussion and Conclusions}

According to the results obtained and the discussion and conclusions, it should be noted that the proposed general objective, which sought to determine whether there is a relationship between the use of the Internet and the social values perceived by university students, has been confirmed, highlighting the variables of gender, age, and academic year. It is highlighted that university students are able to identify that the Internet transmits values in their social relationships with colleagues, friends, and family.

The first hypothesis (H1) affirmed that there is a relationship between the use of the Internet by university students and their perception of social values when using the Internet, according to the variables of gender and academic year ( $p=0.049$, respectively). These results coincide with recent research [69]. In this study, the authors affirm that there is a presence of social values related to the use of the Internet. Additionally, other authors $[70,71]$ demonstrated some differences between the genders in the use of the Internet. Although none of these investigations specify the variables mentioned here, they do specify that there is a generalized tendency for young people to use the Internet and to be aware that some social values are present in their communicative processes.

Likewise, several studies show that young people use the Internet for fun and entertainment, as Cloquel [72] explains. It should be noted that young people are able to use values such as respect and responsibility when communicating on networks.

Therefore, the responsible and respectful use of communication through the networks contrasts with hypothesis $\mathrm{H} 2$, which states that university students are able to identify social values when using the Internet to communicate and entertain themselves according to gender $(p=0.029)$, age $(p=0.045)$, and academic year $(p=0.031)$, as Viñals [73] has also stated that young people perceive the Internet as a means to relate, communicate, inform themselves and also entertain themselves, especially highlighting friendship, cooperation, freedom, and responsibility.

In relation to the following hypotheses, it should be noted that there is a relationship between the use of the Internet and the promotion of values according to gender (0.041), age (0.026), and academic year (0.045) in university students (H3). Another hypothesis that has been tested is that young people are aware of the use of the Internet when they communicate with their peers and the values that are promoted (H4), taking into account gender $(p=0.022)$, age $(p=0.027)$, and academic year $(0.021)$. This hypothesis $(\mathrm{H} 4)$ is contrasted by stating that there is a relationship between Internet use and the social values 
transmitted when students communicate with friends through the Internet according to sex (0.004), age (0.004), and academic year (0.004). All the previous hypotheses are contrasted with the studies defended by Ballesta, Lozano, Cerezo, and Soriano [74], in which they affirm that $80.7 \%$ of the young people surveyed do not admit strangers on social networks, which shows that students act responsibly. According to Miralles [75], in social networks, there are languages, modes of expression, values, and lifestyles that influence the identity of young people. This implies that social values are acquired. For example, Olcott et al. [76] emphasize that to achieve an ethically mature society, the construction of individual and collective values must develop throughout the life cycle of the person.

Likewise, another hypothesis (H6) has also been contrasted, which states that there is a significant relationship between the use of the Internet by young university students and the identification of social values when they communicate with family members according to gender $(p=0.035)$, age $(p=0.048)$, and academic year $(0.041)$. Aspects that contrast with another study, in which the importance of the use of technologies and social networks, and the presence of social values among young people when communicating with peers, was seen [77]. In short, some facts that stand out from the study and according to the contrasted hypotheses is that most university students use the Internet and are able to identify social values and use them when communicating with classmates, friends, and family; although, certain differences when considering the variables studied and analyzed (gender, age, and academic year) must be taken into account.

Following the results of the study presented, as well as other cited and contrasted research, it is important to educate young people to be responsible when using the Internet and, in particular, when communicating through social networks, as stated by Martínez Ten [78] in a guide for teachers that aims to promote the ethical and responsible use of social networks. Encouraging the use of the Internet and social networks in the university environment [79], promotes an increase in student motivation, cooperation, collaboration and group cohesion, responsibility, independence, dialogue, communication, critical thinking, and the freedom to organize and develop work, favoring positive attitudes, specific skills, and values among students. This study is also relevant to identify how young people perceive the presence of values on the Internet, especially since "the change in the values of society is indicative of the change in the social structure" [80] (p. 3). Developing university teaching practices in which values, attitudes, and competencies are promoted, is necessary to support adequate self-esteem among young people. This is to say, to improve social and communicative skills that allow them to solve their problems, manage their emotions, and develop protective factors against the risks that social networks and the Internet may pose [81-85].

\section{Limitations and Future Research}

In relation to some of the limitations and future lines of research, it is worth highlighting the need to extend the sample to percentages of students from more universities, since the current results reduce the generalization of the findings to a cohort of university participants who perceive social values in the use of the Internet.

In addition, it is recommended that research combined with the collection of information from teachers and management teams of higher education institutions be considered. Likewise, although it is not the object of this study to address risks derived from inappropriate Internet use, it is evident there is a need to investigate in more depth the perceptions young people have about Internet risks, analyze the components, and measure any impact on them [86]. This is because there is evidence that such inappropriate use is related to problems of self-esteem and impulsivity or depression [87], therefore, to the acquisition of certain social values or counter-values.

Author Contributions: All the authors made substantial contributions to the conception and design of the work, the analysis, and the consideration of the main conclusions. All the authors approved the submitted version. All the authors agreed to be personally accountable for their own contributions and for ensuring that questions related to the accuracy or integrity of any part of the work, even ones in which the author was not personally involved, were appropriately investigated, resolved, 
and documented in the literature. The individual contributions to the sections of the manuscript are specified as follows: introduction and conclusions, M.C.C.-P., B.G.-L. and P.R.-A.; material, method, and formal analysis, C.G.A.-H. and P.R.-A.; writing-original draft preparation, review, and editing, M.C.C.-P., C.G.A.-H., B.G.-L. and P.R.-A. All authors have read and agreed to the published version of the manuscript.

Funding: This work is conducted within the framework of 'Alfamed' (Euro-American Network of Re-searchers), with the support of the R+D Project "YOUTUBERS AND INSTAGRAMMERS: MEDIA COMPETENCE IN EMERGING PROSUMERS" (RTI2018-093303-B-I00), financed by the State Re-search Agency of the Spanish Ministry of Science, Innovation and Universities, and the European Regional Development Fund (ERDF).

Institutional Review Board Statement: Not applicable.

Informed Consent Statement: Not applicable.

Data Availability Statement: Not applicable.

Conflicts of Interest: The authors declare no conflict of interest.

\section{References}

1. Rial, A.; Gómez, P.; Braña, T.; Varela, J. Actitudes, percepciones y uso de Internet y las redes sociales entre los adolescentes de la comunidad gallega (España). An. Psicol. 2014, 30, 642-655. [CrossRef]

2. Aslanidou, S.; Menexes, G. Youth and the Internet: Uses and practices in the home. Comput. Educ. 2008, 51, 1375-1391. [CrossRef]

3. Ruiz-Olivares, R.; Lucena, V.; Pino, M.J.; Herruzo, J. Análisis de comportamientos relacionados con el uso/abuso de Internet, teléfono móvil, compras y juego en estudiantes universitarios. Adicciones 2010, 22, 301-310. [CrossRef]

4. Dentzel, Z. El impacto de internet en la vida diaria. In C@mbio: 19 Ensayos Clave Sobre Cómo Internet Está Cambiando Nuestras Vidas; BBVA: Madrid, Spain, 2013.

5. Velasquez, D.; Renó, A.M.; Beltrán, J.C.; Maldonado; Ortiz León, C. From the mass media to social media: Reflections on the new media ecology. Rev. Lat. Comun. Soc. 2018, 73, 583-594. [CrossRef]

6. Salaverría, R.; Sádaba, C.; Breiner, J.G.; Warner, J.C. A brave new digital journalism in Latin America. In Communication: Innovation E Quality; Túñez-López, M., Martínez-Fernández, V.A., López-García, X., RúasAraujo, J., Campos-Freire, F., Eds.; Springer International Publishing: Cham, Switzerland, 2019; pp. 229-247.

7. Nguyen, M.H.; Gruber, J.; Fuchs, J.; Marler, W.; Hunsaker, A.; Hargittai, E. Changes in Digital Communication during the COVID-19 Global Pandemic: Implications for Digital Inequality and Future Research. Soc. Med. + Soc. 2020, 6. [CrossRef]

8. Marañón, C.O. Redes Sociales y Jóvenes: Una Intimidad Cuestionada en Internet. Aposta. Rev. Cienc. Soc. S 2012, 54, 1-16. Available online: https:/ / bit.ly/2YIHSzj (accessed on 1 October 2021).

9. Cívico-Ariza, A.; Colomo-Magaña, E.; González-García, E.; Sánchez-Rivas, E. Volunteering in the University Context: Student Perception and Participation. Educ. Sci. 2020, 10, 380. [CrossRef]

10. Lozares-Colina, C. La Teoría de Redes Sociales. Pap. Rev. Soc. 1996, 48, 103-126.

11. Campos-Freire, F.; Rúas-Araújo, J. Las Redes sociales Digitales en el Ecosistema Mediático; Cuadernos Artesanos de Comunicación de Latina de Comunicación Social: Tenerife, Spain, 2015. [CrossRef]

12. Chiang, I.-P.; Huang, C.-Y.; Huang, C.-W. Traffics metrics and Web 2.0-ness. In Online Information Review; Emerald Group Publishing Limited: Taiwan, 2010; Volume 34, pp. 115-126.

13. Túñez, M.; y Sixto, J. Las redes sociales como entorno docente: Análisis del uso de Facebook en la docencia universitaria. Píxel-Bit. Rev. Medios Educ. 2012, 41, 77-92.

14. Smith, M.; Kollock, P. (Eds.) Comunidades en el Ciberespacio; UOC. Colección Nuevas Tecnologías y Sociedad: Barcelona, Spain, 2003.

15. Bauman, Z. Vivimos en dos Mundos Paralelos y Diferentes: El Online y el Offline. 2014. Available online: http://goo.gl/OH8If5 (accessed on 1 October 2021).

16. García-Ruiz, R.; Ramírez-García, A.; Rodríguez-Rosell, M. Media literacy education for a new prosumer citizenship. Comunicar 2014, 43, 15-23. [CrossRef]

17. Castells, M. Internet y la Sociedad Red. 2001. Available online: https://bit.ly/2LhuaRa (accessed on 1 October 2021).

18. Viñals Blanco, A. Las Redes Sociales Virtuales Como Espacios de Ocio Digital. Fonseca J. Commun. 2013, 6, 150-176. Available online: https: / / revistas.usal.es/index.php/2172-9077/article/view/12089 (accessed on 1 October 2021).

19. Rubio-Romero, J.; Jiménez, J.; Barón-Dulce, G. Las redes sociales digitales como espacios de sociabilidad de los adolescentes. El caso del colegio Escolapios de Aluche. Rev. Med. Comun. 2019, 10, 85-99. [CrossRef]

20. Marín Pacheco, A. Jóvenes y Redes Sociales Valores y Miedos Heredados de las Culturas de Internet. Telos 2012, 9, 116-125. Available online: https:/ / bit.ly/3cz2kuX (accessed on 1 October 2021).

21. Turégano Mansilla, I. Los valores detrás de la privacidad. Doxa. Cuad. Filos. Derecho 2020, 255-283. [CrossRef] 
22. López Berlanga, M.C.; Sánchez Romero, C. La interacción y convivencia digital de los estudiantes en las redes sociales. Rev. Educ. Inclusiva 2019, 12, 114-130.

23. Cabero, J.; Pérez-Díez, J.L.; Valencia-Ortiz, R. Escala para medir la adicción de estudiantes a las redes sociales. Converg. Rev. Cienc. Soc. 2020, 27, 1-29. [CrossRef]

24. UNESCO Replantear la Educación. ¿Hacia un Bien Común Mundial? 2015. Available online: https://bit.ly/3cz2kuXhttps: / / bit.ly/39pP5Zu (accessed on 1 October 2021).

25. Trigwell, K.; Prosser, M. Development and Use of the Approaches to Teaching Inventory. Educ. Psychol. Rev. 2004, 16, 409-424. [CrossRef]

26. Caldeiro, M.C.; Aguaded-Gómez, J. “Estoy Aprendiendo, no me Molestes” la Competencia Mediática Como Forma de Expresión Crítica de Nativos e Inmigrantes Digitales. 2015. Redes.com, 12. Available online: http://goo.gl/2ORkf1 (accessed on 15 December 2020).

27. Pérez-Tornero, J. The future of the digital society and values in media education. [El futuro de la sociedad digital y los nuevos valores de la educación en medios]. Comunicar 2005, 25, 247-258. [CrossRef]

28. Canavilhas, J. El Nuevo Ecosistema Mediático. Index. Comun. 2011, 1, 13-24. Available online: https://bit.ly/3trQRTO (accessed on 1 October 2021).

29. Cotino, L. La enseñanza digital en serio y el derecho a la educación en tiempos del coronavirus. Revista de educación y derecho. Educ. Law Rev. 2020, 21, 1-29. [CrossRef]

30. Adell, J. Wikis en educación. In Posibilidades de la Teleformación en el Espacio Europeo de Educación Superior; Cabero, J., Barroso, J., Eds.; Editorial Octaedro: Andalucía, Spain, 2007; pp. 323-333.

31. Rodicio-García, M.L.; Ríos-de-Deus, M.P.; Mosquera-González, M.J.; Penado Abilleira, M. La Brecha Digital en Estudiantes Españoles ante la Crisis de la Covid-19. Rev. Int. Educ. Para Justicia Soc. 2020, 9, 103-125. [CrossRef]

32. Naciones Unidas Informe de los Objetivos de Desarrollo Sostenible. 2016. Available online: https://unstats.un.org/sdgs/report/ 2016/The\%20Sustainable\%20Development\%20Goals\%20Report\%202016_Spanish.pdf (accessed on 1 October 2021).

33. Morales, F.; Trianes, M.V.; Infante, L. Perfiles de valores éticos en estudiantes universitarios. Aula Abierta 2013, $41,55-66$.

34. Ferrer, R. La Generación del Milenio Los Millennials, ¿Quiénes Son? Caixabank Research. 2018. Available online: https: / / bit.ly/3rvmYjS (accessed on 1 October 2021).

35. Briones, E.; Gómez- Linares, A.; Palomera, R. Psicología positiva en las aulas de magisterio con bitácora, debate, abp y teatro. Rev. INFAD De Psicología. Int. J. Dev. Educ. Psychol. 2019, 4, 191-204. [CrossRef]

36. López-Carrasco, M. Aprendizajes, Competencias y TIC; Pearson: Madrid, Spain, 2017.

37. Moreno Martín, M.J. Active Methodologies and the Curriculum. Revista Ventana Abierta, 29. 2018. Available online: https: / / bit.ly/39KMDyG (accessed on 1 October 2021).

38. Konopka, C.L.; Bohrer Adaime, M.; Henrique Mosele, P. Active Teaching and Learning Methodologies: Some Considerations. Creat. Educ. 2015, 6, 1536-1545. [CrossRef]

39. Durlak, J.A.; Weissberg, R.P.; Dymnicki, A.B.; Taylor, R.D.; Schellinger, K.B. The impact of enhancing students' social and emotional learning: A meta-analysis of school-based universal. Child Dev. 2011, 82, 405-432. [CrossRef]

40. Vallejo, M.; Molina, J. Análisis de las Metodologías Activas en el Grado de Maestro en Educación Infantil: La Perspectiva del Alumnado. REIFOP 2011, 14, 207-217. Available online: https: / bit.ly/35Jvq5n (accessed on 2 October 2021).

41. Bisquerra, R.; Pérez, N. Las competencias emocionales. Educ. XXI 2007, 10, 61-82. [CrossRef]

42. CASEL (Collaborative for Academic, Social, and Emotional Learning). Safe and Sound: An Educational Leader's Guide to Evidence-Based Social and Emotional Learning Programs. Illinois Edition. 2005. Available online: https://files.eric.ed.gov/ fulltext/ED505373.pdf (accessed on 1 October 2021).

43. Gertrudis-Casado, M.; Gértrudix-Barrio, M.; Álvarez-García, S. Professional information skills and open data. Challenges for citizen empowerment and social change. Comunicar 2016, 47, 39-47. [CrossRef]

44. Cristofani, M.A. El Nuevo Consumidor De Información: ¿Usuario O Productor? El Re-Planeamiento Estratégico de Las Unidades de Información. Trabajo Presentado en V Jornadas de Intercambio y Reflexión Acerca de la Investigación en Bibliotecología. Universidad Nacional de La Plata, Facultad de Humanidades y Ciencias de la Educación, La Plata. 2017. Available online: https: / / bit.ly /3cPH9F8 (accessed on 1 October 2021).

45. Hernández-Serrano, M.; Renés-Arellano, P.; Graham, G.; Greenhill, A. From prosumer to prodesigner: Participatory news consumption. Comunicar 2017, 50, 77-88. [CrossRef]

46. Plaza, J.d.1.H. Ventajas y desventajas del uso adolescente de las TIC: Visión de los estudiantes. Rev. Complut. De Educ. 2017, 29, 491-508. [CrossRef]

47. Ferrari, J.R.; Kapoor, M.; Cowman, S. Exploring the relationship between students' values and the values of postsecondary institutions. Soc. Psychol. Educ. 2005, 8, 207-221. [CrossRef]

48. Pérez-Tornero, J. Multi-screen society: A challenge for media literacy. Comunicar 2008, 31, 15-25. [CrossRef]

49. García, M.J.M.; Castro, A.M.P. La investigación en educación. In Notas Teórico-Metodológicas de Pesquisas em Educação: Concepções e Trajetórias; Mororó, 1.P., Couto, M.E.S., Assis, R.A.M., Eds.; Editus: Ilhéus, Brazil, 2017; pp. 13-40. [CrossRef]

50. Gómez, M. Introducción a la Metodología de la Investigación Científica; Editorial Brujas: Córdoba, Spain, 2006.

51. Hernández-Sampieri, R.; Mendoza-Torres, C.P. Metodología de la Investigación. Las Rutas Cuantitativa, Cualitativa y Mixta; Editorial McGrawHill: New York, NY, USA, 2018. 
52. Barba Martín, L.; Alcántara Santuario, A. Los Valores y la Formación Universitaria. Reencuentro 2003, 38, 16-23. Available online: https:/ / bit.ly/3afoSz9 (accessed on 15 January 2021).

53. Albizuri, I.E.; Gallego, 1.V.; Eulate, C.Y.Á.d. Identificación y desarrollo de valores en estudiantes universitarios. Rev. Educ. 2013, 362, 186-216. [CrossRef]

54. Malinowska, B.K. Valores en los Estudiantes Universitarios. Un Tema con Muchas Variaciones. Reencuentro 2003, 38, 48-56. Available online: https:/ / bit.ly /3pdKVub (accessed on 23 May 2021).

55. Díaz-Muñoz, G. Metodología del estudio piloto. Rev. Chil Radiol. 2020, 26, 100-104. [CrossRef]

56. Albornoz-Arias, N.; Contreras-Velásquez, J.C.; Espinosa-Castro, J.F.; Sotelo Barrios, M.E. Capacidades emprendedoras en población de la pirámide en Cúcuta, Colombia. Contaduría Adm. 2021, 66, 1-23. [CrossRef]

57. Otzen, T.; Manterola, C. Técnicas de Muestreo sobre una Población a Estudio. Int. J. Morphol. 2017, 35, 227-232. [CrossRef]

58. Hernández, C.; y Carpio, N. Introducción a los tipos de muestreo. Rev. Alerta 2019, 2, 74-79. [CrossRef]

59. Acuña, I.; Michelini, Y.; Guzmán, J.I.; Godoy, J.C. Evaluación de validez convergente y discriminante en tests computarizados de toma de decisiones. Avaliação Psicológica 2017, 16, 375-383. [CrossRef]

60. Suárez, A. La estadística en la validación de escalas, una visión práctica para su construcción o su adaptación. Rev. I3+ 2015, 2, 46-61.

61. Cardona-Arias, J.A.; Ospina-Franco, L.C.; Eljadue-Alzamora, A.P. Validez discriminante, convergente/divergente, fiabilidad y consistencia interna, del whoqol-bref y el mossf-36 en adultos sanos de un municipio colombiano. Rev. Fac. Nac. Salud Pública 2015, 33, 50-57.

62. Jiménez, A.; Garza, A.; Méndez Flores, C.; Mendoza Carrillo, J.; Acevedo, J.; Arredondo, L.C.; y Quiroz, S. Motivación hacia las matemáticas de estudiantes de bachillerato de modalidad mixta y presencial. Rev. Educ. 2020, 44. [CrossRef]

63. Soler Cárdenas, S.; Soler Pons, L. Usos del Coeficiente alfa de Cronbach en el Análisis de Instrumentos Escritos. Rev. Méd. Electrónica 2012, 34, 1-6. Available online: https: / / cutt.ly / 8RLjQo8 (accessed on 25 December 2020).

64. Romero-Saldaña, M. Pruebas de bondad de ajuste a una distribución normal. Rev. Enfermería Del Trab. 2016, 6, 105-114.

65. Herrera, M.; Guerra, C.; Sarduy, L.; García, Y.; y Martínez, C.E. Diferentes métodos estadísticos para el análisis de variables discretas. Una aplicación en las ciencias agrícolas y técnicas. Rev. Cienc. Técnicas Agropecu. 2012, 21, 58-62.

66. Flores-Ruiz, E.; Miranda-Novales, M.G.; y Villasís-Keever, M.Á. El protocolo de investigación VI: Cómo elegir la prueba estadística adecuada. Estadística inferencial. Rev. Alerg. México 2017, 64, 364-370. [CrossRef]

67. Martínez, R.M.; Tuya, L.; Martínez, M.; y Pérez, A. El Coeficiente de Correlación de los Rangos de Spearman Caracterización. Rev. Habanera De Cienc. Médicas 2009. Available online: https: / cutt.ly/PRLj3if (accessed on 1 October 2021).

68. Mondragón, M.A. Uso de la correlación de Spearman en un estudio de intervención en fisioterapia. Mov. Científico 2014, 8, 98-104. [CrossRef]

69. Renes-Arellano, P.; Alvites-Huamaní, C.G.; Caldeiro-Pedreira, M.-C. La transmisión de valores sociales a través de Internet. Aula Abierta 2020, 49, 113-120. [CrossRef]

70. Díaz-Vicario, A.; Mercader, C.; Gairín, J. Uso problemático de las TIC en adolescentes. Rev. Electrónica Investig. Educ. 2019, 21 , e07. [CrossRef]

71. López de Hoyos, Y. Las Redes Sociales Determinan la Identidad y el Sistema de Valores de los Adolescentes. 2017. Available online: https: / / bit.ly/375iMPO (accessed on 1 October 2021).

72. Cloquell, A. Usos sociales de internet entre los adolescentes españoles. Rev. Sobre Infanc. Adolesc. 2015, 8, 1-14. [CrossRef]

73. Viñals, A. La Experiencia de E-ocio de los Jóvenes. Lúdica Pedagógica 2016, 23, 93-103. Available online: https://bit.ly/3abEDqS (accessed on 1 October 2021).

74. Ballesta, F.J.; Lozano, J.; Cerezo, M.C.; Soriano, E. The internet, social networks and adolescence: A study based on secondary schools of the region of Murcia. Rev. Fuentes 2015, 16, 109-130. [CrossRef]

75. Miralles, R. Cultura Juvenil, Consumismo y Medios de Comunicación. 2008. Available online: https:/ / cutt.ly/aRLka20 (accessed on 8 July 2021).

76. Olcott, D., Jr.; Carrera Farran, X.; Gallardo Echenique, E.E.; González Martínez, J. Ética y Educación en la era digital: Perspectivas globales y estrategias para la transformación local en Cataluña. RUSC. Univ. Knowl. Soc. J. 2015, 12, 59-72. [CrossRef]

77. Morais, C.; Alves, P.; Miranda, L.; Renés Arellano, P. The Internet and Values in Society: Higher Education Students's Perspectives. Rev. Prism. Soc. 2019, 26, 94-115. Available online: https:/ / bit.ly/3ahQlQV (accessed on 14 February 2021).

78. Martínez Ten, L. Guía Para el Profesorado. Ciudadanía 3.0. Educar Para el Uso Ético y Responsable de las Redes Sociales; ISCOD-PV: Madrid, Spain, 2018; Available online: https:/ / bit.ly/3scHlnl (accessed on 10 September 2021).

79. Gómez-Aguilar, M.; Roses-Campos, S.; Farias-Batlle, P. The academic use of social networks among university students. Comunicar 2012, 38, 131-138. [CrossRef]

80. Bolat, Y.; Korkmaz, C. Social Values and Life Skills as Predictors of Organizational Culture: A Study on Teachers. SAGE Open 2021, 11. [CrossRef]

81. Browning, M.H.E.M.; Larson, L.R.; Sharaievska, I.; Rigolon, A.; McAnirlin, O.; Mullenbach, L.; Cloutier, S.; Vu, T.M.; Thomsen, J.; Reigner, N.; et al. Psychological impacts from COVID-19 among university students: Risk factors across seven states in the United States. PLoS ONE 2021, 16, e0245327. [CrossRef]

82. Almahasees, Z.; Mohsen, K.; Amin, M.O. Faculty's and Students' Perceptions of Online Learning during COVID-19. Front. Educ. 2021, 6, 638470. [CrossRef] 
83. Hasking, P.; Lewis, S.P.; Bloom, E.; Brausch, A.; Kaess, M.; Robinson, K. Impact of the COVID-19 pandemic on students at elevated risk of self-injury: The importance of virtual and online resources. Sch. Psychol. Int. 2021, 42, 57-78. [CrossRef]

84. Echeburúa, E.; Requesens, A. Adicción a las Redes Sociales y a Las Nuevas Tecnologías en Jóvenes y Adolescentes; Pirámide: Madrid, Spain, 2012.

85. Lee, J.; Han, K.H. Difference analysis of risk and protection factors for internet addiction between computer science gifted students and average students. J. Gift. Talent. Educ. 2010, 20, 1005-1026.

86. Ramos-Soler, I.; López-Sánchez, C.; Torrecillas-Lacave, T. Online risk perception in young people and its effects on digital behaviour. Comunicar 2018, 56, 71-79. [CrossRef]

87. De la Villa Moral-Jiménez, M.; Fernández-Domínguez, S. Uso problemático de internet en adolescentes españoles y su relación con autoestima e impulsividad. Av. En Psicol. Latinoam. 2019, 37, 103-119. [CrossRef] 